\title{
Motility i kosmopolityczny wymiar transnarodowych związków na odległość
}

\section{Abstract \\ Motility and the Cosmopolitan Dimension of Transnational Long-distance Relationships}

In the times of emphasized fluidification mobility becomes self-evident and naturalized, though socially desirable and anticipated. By following research participant strategies and practices, this paper analyzes the meaning of terms such as privileged and naturalized mobility, cosmopolitanism and transnationalism, and shows its multi-dimensional character. Based on the author's ethnographic fieldwork conducted in 2016-2018 among young, educated and highly mobile Poles and foreigners who live in transnational long-distance relationships and an auto-ethnographic perspective, this article examines the notions of motility, cosmopolitanism and transnationalism and shows how mobility is rooted in their everyday lives. In this specific ethnographic context, transnational longdistance relationship is a verification tool of interlocutor practices and cultural competence that are needed to maintain the relation in the times of individualizing modernity.

Keywords: cosmopolitanism, motility, mobility, structure, transnationalism

Wzmożona mobilność, spowodowana między innymi zwiększeniem możliwości podejmowania studiów za granicą, wymian studenckich, w tym uczestniczenia w programach Erasmus, ale także migracji zarobkowej, umocniła podłoże do zawiązywania się związków transnarodowych, a w tym relacji na odległość. Ponadto pewne zjawiska, takie jak intensywny rozwój technologiczny, zniesienie roamingu w krajach Unii Europejskiej czy bezpłatna komunikacja internetowa, znacznie ułatwiły komunikację zapośredniczoną przez technologie, czyniąc ją niemalże natychmiastową. W przypadku przeprowadzonych przeze mnie w latach 2016-2018 badań na temat transnarodowych związków na odległość technologia 
stanowi kluczowe narzędzie służące utrzymaniu i rozwijaniu romantycznej relacji. Uczestnicy moich badań to młodzi, wykształceni, mobilni, żyjący w dużych miastach Polacy, którzy tworzą intymne związki z ludźmi z Europy i spoza jej granic. Posiadają partnerów z krajów takich jak Stany Zjednoczone, Rumunia czy Argentyna. Życie w związku na odległość z osobą z innego kraju, tworzenie przez młodych ludzi sieci transnarodowych, ich kompetencje kulturowe i stosowane przez nich praktyki nadają kosmopolityczny charakter prowadzonemu przez nich życiu. Celem niniejszego artykułu jest przyjrzenie się tytułowym pojęciom w czasach, w których znaturalizowana mobilność staje się wymogiem, i ukazanie ich ambiwalencji, która ujawnia się poprzez doświadczanie życia w transnarodowym związku na odległość.

\section{Mobilność z wyboru}

Sposób doświadczania życia w związku na odległość może zależeć od czynników indywidualnych, takich jak osobowość, ale również takich jak wiek, kapitał czy mobilność, rozumiana zarówno jako bycie w ruchu - zdolność do przemieszczania się, jak i elastyczność - umiejętność i możliwość ciągłego dostosowywania się do nowych sytuacji.

Badania prowadziłam wśród ludzi młodych, w wieku od 23 do 33 lat, głównie studentów oraz osób, które skończyły studia nie później niż 7 lat temu. Są to Polacy (dokładnie 8 Polek i 1 Polak) oraz cudzoziemcy (10) z różnych krajów: Boliwii, Kolumbii, Norwegii, Belgii, Argentyny, Stanów Zjednoczonych, Szwajcarii, Hiszpanii, Rumunii i Australii. Większość uczestników badań pochodzi ze stolic swoich krajów lub innych większych miast, takich jak np.: Warszawa, Gdańsk, Oslo, Bazylea, Bogota czy Buenos Aires. Kilkoro z rozmówców urodziło się na peryferiach bądź w mniejszych miastach, jednak przeprowadzili się do większych miast w celu uzyskania lepszej edukacji i lepszych perspektyw znalezienia pracy. Co istotne, wszyscy mają dostęp do wysokiego poziomu edukacji, są na drodze zdobywania wyższego wykształcenia lub już je zdobyli. Każdy z moich rozmówców zna co najmniej jeden język obcy ${ }^{1}$. Większość z nich uczestniczyła w programie Erasmus, wyjechała za granicę na studia bądź w celu kontynuowania nauki języka. Są to ludzie, którzy podróżują co najmniej kilka razy w roku w celach edukacyjnych, turystycznych i zarobkowych. Jeśli przyjrzymy się obecnym w antropologii pojęciom rozróżniającym mobilność przymusową i z wyboru, w tym mobilność uprzywilejowaną, moi rozmówcy z pewnością należą do tej drugiej kategorii. Mobilność była częścią ich procesu socjalizacji jeszcze przed wejściem w związek na odległość, jest więc ich nabytą kompetencją kulturową. Część jest już finansowo niezależna, część jeszcze korzysta z pomocy rodziny. Po-

\footnotetext{
1 Wyjątkiem jest Amerykanin Bradley, dla którego angielski jest językiem rodzimym.
} 
mimo wspomnianego już odmiennego podłoża kulturowego to, co ich łączy, to zbliżony kapitał społeczny, ekonomiczny, a czasem również kulturowy (Bourdieu 1984). Kapitał społeczny i kulturowy mogą być widziane jako zbliżone, ponieważ moi rozmówcy dorastali i podlegali procesowi socjalizacji w społeczeństwie, które podkreśla charakterystyczne dla współczesnej kultury Zachodu wartości, takie jak edukacja, kariera czy samorozwój. Są to ludzie wychowani w dyskursie indywidualizmu, który z jednej strony daje pozornie nieograniczoną sprawczość, z drugiej zaś narzuca odpowiedzialność za kształtowanie siebie, sukcesy oraz porażki jednostki.

Chociaż ekonomiczny kapitał grupy badanej może być zróżnicowany, w ostateczności daje możliwość bycia i pozostawania mobilnymi - podróżowania, przemieszczania się w różne miejsca w celach zarówno spotkań z partnerem/partnerką, jak i edukacyjnych czy zarobkowych. Mimo że kwestia regularnego spotykania zależy od tego, jak duży jest dystans między partnerami, możliwość bliższego lub dalszego spotkania jest zawsze na horyzoncie. Te czynniki dają im możliwość sprawowania władzy nad budowaniem życia według własnych wartości, możliwość posiadania w pewnym sensie „dobrego życia” (good life) (Fischer 2014: 2). To wszystko pozwala określić ich mianem grupy społecznie uprzywilejowanej.

\section{Metody badań}

Punktem wyjścia badań jest doświadczenie autoetnograficzne, to właśnie z mojego biograficznego doświadczenia życiowego zrodził się pomysł, by przyjrzeć się transnarodowym związkom na odległość z perspektywy antropologicznej. Chociaż własna perspektywa umożliwiła mi posiadanie wspólnego podłoża empirycznego z moimi rozmówcami, to jednak to ich spojrzenie stoi zarówno w centrum moich badań, jak i niniejszego artykułu.

By poznać i zrozumieć doświadczenia interlokutorów, przeprowadziłam dziewiętnaście ${ }^{2}$ niestrukturyzowanych i pogłębionych wywiadów etnograficznych, którym towarzyszyła obserwacja uczestnicząca ${ }^{3}$. Z partnerami zawsze rozmawiałam osobno, co umożliwiło mi skoncentrowanie się na indywidualnym wymiarze doświadczenia. Dane z wywiadów analizowałam, koncentrując się na doświadczeniu dwóch osobnych jednostek tworzących związek.

Obserwacja uczestnicząca $\mathrm{w}$ większości przypadków również była prowadzona osobno i miała na celu porównanie doświadczeń, deklaracji i praktyk ${ }^{4}$. Łącznie

2 Przeprowadziłam wywiady z dziewięcioma parami oraz z moim własnym partnerem.

3 Artykuł powstał na podstawie jednego $\mathrm{z}$ fragmentów pracy magisterskiej pt. Transnarodowe związki na odległość. Strategie i praktyki, napisanej w lipcu 2018 roku pod kierunkiem dr hab. Karoliny Bielenin-Lenczowskiej. Praca znajduje się w archiwum Instytutu Etnologii i Antropologii Kulturowej Uniwersytetu Warszawskiego.

4 Jednak kilka par miałam okazję obserwować razem przed wywiadami u nich i po nich. 
przebadałam dziewięć par różnych narodowości. W doborze rozmówców posługiwałam się metodą kuli śnieżnej, gdyż ta wydawała się najbardziej adekwatna do wybranego tematu - terenu badań. Końcowa grupa badawcza to głównie Polki z jednym wyjątkiem (para Polak - Kolumbijka), będące w związku z mężczyzną innej narodowości. Podział płciowy nie został utworzony celowo, jednak mógłby stanowić temat dalszych badań. Wywiady zostały przeprowadzone w języku polskim (9), angielskim (9) oraz hiszpańskim (1), na żywo i przez komunikatory internetowe (3).

Co istotne, moi rozmówcy codziennie komunikują się za pomocą różnego rodzaju aplikacji, takich jak Skype, FaceTime, WhatsApp czy Facebook Messenger. Używają zarówno wiadomości tekstowych, jak i nagrywanych, natychmiastowych wiadomości głosowych czy wideoczatów. Większość z nich mówi, że nie wyobraża sobie takiego związku w czasach, gdy jedyną możliwością utrzymania tego rodzaju relacji była droga pocztowa. Dzięki temu, że wszyscy moi rozmówcy, podobnie jak ja, używają wspomnianych aplikacji do codziennego kontaktu między sobą, jest to sposób i pole komunikacji dobrze im znane. Możliwe było zatem uniknięcie sytuacji sztuczności w rozmowie zapośredniczonej przez technologię. Nasze wywiady bardzo często miały charakter dialogiczny, zbliżony do rozmów nieformalnych, często wymienialiśmy się doświadczeniami i refleksjami na dany temat. Planując badania, zakładałam, że moje doświadczenie będę traktowała wyłącznie jako pomocny punkt wyjścia przy uprawianiu tego rodzaju etnografii, lecz z biegiem czasu dostrzegłam $\mathrm{w}$ takim podejściu problem etyczny. $\mathrm{Z}$ uwagi na intymną specyfikę tematu czysto metodologiczne potraktowanie własnego doświadczenia implikujące wyłącznie zadawanie pytań i słuchanie interlokutora, bez dzielenia się przy tym własną perspektywą - wydaje się w pewien sposób nie w porządku wobec rozmówców. Dlatego też podczas wspólnych spotkań dzieliłam się z moimi rozmówcami własnym doświadczeniem.

\section{Motility i flexibility - zdolność i gotowość do bycia mobilnym. Mobilność a struktura społeczna}

Opierając swoje badania na relacjach pomiędzy mobilnością społeczną a przestrzenną, Vincent Kaufmann, Manfred Max Bergman i Dominique Joye opracowali koncept zwany motility, który ukazuje nowe formy nierówności społecznych (Kaufmann, Bergman, Joye 2004). Wychodząc od kapitału w rozumieniu Pierre’a Bourdieu (1984), badacze ci patrzą na mobilność jako formę kapitału społecznego. Motility jest więc używana, by opisać zdolność, a zarazem gotowość jednostki do bycia mobilną. W biologicznym znaczeniu termin ten może oznaczać po prostu ruchliwość, rozumianą jako zdolność do samodzielnego i spontanicznego poruszania się, jednak w rozumieniu badaczy ma on wpisaną pewnego rodzaju potencjalność, opartą na dostępie (access), kompetencji (competence) oraz 
przywłaszczeniu i dostosowaniu do własnego kontekstu (appropriation) ${ }^{5}$. Idąc dalej, koncepcja ta umożliwia zarysowanie sieci relacji pomiędzy jednostką a byciem mobilnym, przedstawia także, w jaki sposób tak definiowany kapitał może łączyć się bądź podlegać wymianie z innymi formami kapitału, takimi jak społeczny, ekonomiczny czy kulturowy. Motility przekracza proste rozgraniczenie na mobilność społeczną i przestrzeń geograficzną poprzez integrację powyższych na poziomie aktorów, kultury, sieci, instytucji i społeczeństwa oraz dopuszczenie nowych form zawiązywania się relacji między siecią komunikacji a terytoriami. Zdaniem autorów pojęcie mobilności jest ograniczone poprzez skoncentrowanie go wyłącznie na ruchu przestrzennym. Dlatego też proponują termin motility, który ma za zadanie wziąć pod uwagę warunki do wykonania ruchu przestrzennego dostęp, kompetencje/umiejętności i plany. Dokonując zestawienia koncepcji kapitału w rozumieniu Bourdieu z motility, ta druga jest, jak sami jej autorzy piszą, terminem szerszym i mniej hierarchicznym. W przeciwieństwie do pojęć Bourdieu motility traktuje pozycję społeczną w sposób wertykalny i horyzontalny zarazem, co umożliwia nadanie jej miana terminu holistycznego. Dzięki plastyczności, a zarazem szerokości tego pojęcia staje się ono narzędziem umożliwiającym badanie indywidualnych perspektyw i dostosowanie ich do różnych kontekstów w dobie wysokiej mobilności i nowoczesności. Wypełnia dotychczasową lukę pojęciową, nie zmuszając badacza do rezygnowania z dotychczasowo poznanych teorii. Koncentrując się na przestrzennej mobilności, autorzy terminu twierdzą, że struktury społeczne i dynamika, jaka między nimi zachodzi, są współzależne $\mathrm{z}$ realną i potencjalną zdolnością do przemieszczania podmiotów, takich jak dobra, informacje czy ludzie (Kaufmann, Bergman, Joye 2004: 745). Takie podejście splata rozumienie pojęcia mobilności z pojęciem struktury społecznej; w tym wypadku mobilność jawi się jako ta, która strukturyzuje życie społeczne. Ruch przestrzenny jest tu widziany jako spójnik pomiędzy jednostkami a relacjami społecznymi, życiem zawodowym, ale także potrzebą konsumpcji i sposobu spędzania czasu wolnego. Sprawczość i wybór, które mobilność uprzywilejowana ze sobą niesie, powinny być postrzegane raczej jako sposób strukturowania życia poprzez możliwości, jakie dają współczesne systemy i technologie dostarczające wirtualnych, fizycznych i komunikatywnych form mobilności, nie zaś jako indywidualny, nieuwarunkowany, wolny wybór. Pojęcie motility pozwala badaczom łączyć ze sobą społeczną i przestrzenną mobilność. Sven Kesselring podziela ten pogląd, podkreślając, że mobilność nie może być widziana jako całkowita, czysta wolność, a raczej powinna być rozważana w kategoriach indywidualnych potrzeb, życzeń, wymagań adaptowanych do kolektywnych założeń i oczekiwań względem mobilności, ujętej tu jako proces kreacji życia jednostki poprzez ruch, przy jednoczesnej adaptacji heteronomicznych zasad i struktur (Kesselring 2006). Cechy, którymi odznacza się grupa moich rozmówców, to bycie młodym, wykształco-

5 O ile nie zaznaczono inaczej, wszystkie tłumaczenia w niniejszej pracy są mojego autorstwa - A.S. 
nym, lecz jeszcze niezdefiniowanym przez wykonywany zawód, jeszcze nieprzywiązanym do pracy, którą się wykonuje, bądź do miejsca, w którym obecnie się mieszka, a zatem (potencjalnie) elastycznym. Istotny jest tu również fakt, że nikt $\mathrm{z}$ moich rozmówców nie ma (jeszcze) dzieci. Ponadto z uwagi na układ, w jakim żyją z partnerem/partnerką, pozostają oni w ciągłej gotowości do bycia mobilnym. Gotowość ta jest wpisana w teraźniejszość - planowanie najbliższych spotkań, ale także w przyszłość - plany długo wyczekiwanego zamieszkania w jednym miejscu. Wszyscy moi rozmówcy postrzegają związek na odległość jako sytuację tymczasową i pozostają zgodni co do tego, że relacja długodystansowa musi się skończyć. Jak zauważa Kaufmann, istnieje związek między elastycznością (flexibility) a umiejętnością wprowadzenia w życie pomysłów i planów. To, co je łączy, to motility (Kaufmann, Bergman, Joye 2004). W przypadku moich interlokutorów czas, tymczasowość i jednoczesność odgrywają znaczącą rolę w sposobie patrzenia na wyzwania, jakie niesie za sobą związek na odległość. Ich wiek i bycie w momencie życiowym, w którym wiele decyzji nie zostało jeszcze podjętych, wpływa na ich gotowość i zdolność do bycia mobilnym (motility). Wielu z nich deklaruje gotowość zarówno do bycia, jak i pozostawania w ruchu z uwagi na własne wybory lub wybory partnera/partnerki. Moja rozmówczyni Valentina - Kolumbijka, która niedawno przeprowadziła się do Warszawy do swojego chłopaka Jana, tak opisuje swoją sytuację:

Zdecydowaliśmy, że Warszawa będzie lepszą opcją... Ale nigdy... Sądzę, że jeśli pewnego dnia opcja przeprowadzki gdzieś indziej się pojawi, to będzie z nami dobrze. Myślę o sobie i o Janku, że my się bardzo dobrze dostosowujemy, mieszkaliśmy już gdzie indziej, mieszkaliśmy już w Australii (podczas kursu językowego, na którym się poznali - A.S.), dużo podróżujemy i za każdym razem, gdy podróżujemy, radzimy sobie razem. Używamy do tego jego i mojej siły.

Dan jest z Gosią, z którą utrzymują związek na odległość między Polską a Belgią. Tak mówi o planach przeprowadzki: „Polska była pierwsza, ale może po jej doktoracie pomyślimy o innym kraju na rok, dwa, trzy lata albo jeśli naprawdę Polska nie będzie mi pasować, wtedy będzie to Belgia albo inny kraj”. Mimo że grupa rozmówców cechuje się wyraźnym elementem elastyczności wynikającym $\mathrm{z}$ ich wieku bądź momentu w życiu, związek na odległość powoduje, iż muszą oni planować przyszłość znacznie dokładniej, niż robią to ich rówieśnicy. Z jednej strony są to ludzie wyraźnie nastawieni i otwarci na mobilność, z drugiej systematycznie planujący.

Moi rozmówcy często wyrażają $\mathrm{w}$ wywiadach przekonanie, że związek na odległość nie jest tym samym, czym związek „normalny”. Długo wyczekiwane, faktyczne (fizyczne) spotkania często przypominają wakacje bądź w istocie są krótszymi lub dłuższymi wakacjami samymi w sobie, podczas gdy „życie razem, ale osobno" jest samotne i emocjonalnie trudne. By nad tym zapanować, wielu z moich rozmówców wyraża potrzebę posiadania struktury opartej na planowaniu i organizowaniu czasu oraz ruchu. Dwudziestoczteroletni Tom, który urodził 
się w Australii, ale mieszka i żyje od wielu lat w Anglii, zapytany o to, jak radzi sobie z czasem, gdy nie widzi swojej dziewczyny, odpowiedział tak:

T.: Hmm...To jest ciężkie... Czasem tęsknimy za sobą, ale wiesz, skupiamy się na tym momencie, wiemy, co się dzieje dookoła nas. Planujemy, upewniamy się, że mamy plany na przyszłość, że wiemy, kiedy się zobaczymy, możemy cieszyć się tym czasem razem. Bo bilety są tańsze... Więc musimy organizować zawczasu, długofalowo. Nie da się tego obejść. Musisz kupić bilety trzy miesiące wcześniej, dwa miesiące wcześniej, szczególnie na wakacje, więc planujesz z góry, żeby wiedzieć, że utrzymasz kontakt.

A.S.: Zawsze tak jest, że kiedy się żegnacie, wiecie, kiedy się znowu zobaczycie?

T.: Tak, zawsze jest plan. Zawsze jest coś. Posiadanie tego jest dobre. To pomaga ci uświadomić sobie, że potrzebujesz struktury. Struktura jest bardzo ważna w związku, żeby ludzie mogli się czuć komfortowo, a czują się bardziej komfortowo, kiedy mają struktury. Ja byłem mniej niż ona... z tym... Mam na myśli strukturę. Ale zacząłem sobie zdawać z tego sprawę coraz bardziej, że struktura jest bardzo ważna. Przedtem byłem taki „Eee, okej”, a Nela była bardziej nastawiona na organizowanie... Nie dlatego, że nie chciałem tego widzieć, po prostu byłem leniwy. Ale teraz uświadomiłem sobie, że to ważne. Teraz to robię.

W momencie przeprowadzenia wywiadu Tom i Nela byli ze sobą od półtora roku, utrzymując związek między Mediolanem, gdzie Nela kończyła studia magisterskie, a Londynem, gdzie Tom podjął tymczasową pracę w start-upie. Podczas wywiadu powiedzieli, że cały czas zmagają się z decyzją, gdzie zamieszkać. Decyzja ta zależała od tego, kto i gdzie pierwszy znajdzie pracę. Inna para, Vlad i Ania, poznali się w międzynarodowej firmie jubilerskiej. Vlad pochodzi z Rumunii, ma 33 lata i pracuje w dziale IT, Ania ma 29 lat i jest coachem biznesowym. W momencie wywiadu podjęli już decyzję o przeprowadzce Vlada do Warszawy. Zapytałam, jak podejmowali decyzję o wspólnym zamieszkaniu.

Był plan B, gdyby Warszawa nie wyszła. Znaczy, jeśli nie mógłbym znaleźć tu pracy. Była opcja przeprowadzki do Belgii. Dlatego, że ona tam studiowała, zna i lubi ten kraj. Ja mówię trochę po francusku, byłem też w Belgii jakiś tydzień i bardzo mi się podobała. I był taki moment jakieś trzy lata temu, kiedy byłem między jedną pracą a drugą i bardzo chciałem wyjechać już z Rumunii, no i Belgia była takim pierwszym wyborem.

Powyższy cytat wskazuje, z jakim znaczącym wyprzedzeniem moi rozmówcy muszą planować swój czas, aby utrzymać związek. Oddaje ciągłą gotowość do zmiany, dostosowania się do drugiej osoby, ale też do okoliczności. Zarówno krótko- jak i długofalowe planowanie kontaktu codziennego (dotyczy to w szczególności par, które zmagają się z różnicą czasu), jak również fizycznych spotkań staje się z jednej strony potrzebą, z drugiej zaś wymogiem utrzymania relacji. Konieczność dokładnego planowania przyczynia się do budowania poczucia odmienności relacji na odległość. Zazwyczaj osoby młode, żyjące ze sobą w jednym mieście, nie muszą rozrysowywać planu spotkań na najbliższe tygodnie bądź miesiące. W przypadku związku na odległość jest to jedyna możliwość. Brak dzielonej fizycznie codzienności, a więc dystans i przestrzeń dzieląca osoby w związku są łączone z założonym zaufaniem do drugiej osoby. Dla wielu par 
funkcjonowanie relacji na odległość stanowi potwierdzenie cech potrzebnych do budowania związku, takich jak siła, wytrwałość czy zaufanie. Bradley opisał to tak: „Jest tu takie bezwzględne zaufanie, to jedyny sposób, żeby to zadziałało... Musisz po prostu skoczyć z tego klifu i liczyć na to, że wylądujesz...”.

Istnieje zatem wewnętrzna potrzeba posiadania struktury związku, która pełni funkcję normatywizowania relacji na odległość i zbliżania jej do codziennej fizycznej relacji. Planowanie jest strategią zdobywania kontroli nad tym, co niepewne. Ta sama struktura narzuca jednak praktyki dotyczące mobilności, które jednocześnie konstytuują związek na odległość. W kontekście przeprowadzonych przeze mnie badań motility stanowi także podstawę do postrzegania moich rozmówców w kategoriach kosmopolitów.

\section{Kosmopolityzm jako praktyka i kompetencja kulturowa}

Słowo kosmopolityzm zdaje się odległe od klasycznych podejść antropologicznych, które koncentrowały się zwykle na konkretnych, często oddalonych, odizolowanych od większych ośrodków społecznościach. Kosmopolityzm, widziany jako wbudowany w europejską świadomość liberalno-elitarną, nie jest pierwszym terminem kojarzonym $\mathrm{z}$ antropologią. Jednak $\mathrm{w}$ dobie postmodernizmu, globalizacji i rosnącej mobilności powinien również zostać włączony do rozważań antropologicznych (zob. Werbner 2008).

Etymologia terminu „kosmopolityzm” wywodzi się z greckiego cosmos (wszechświat, kosmos), polis (miasto) czy też cosmopolites (obywatel świata). Nowy normatywny kosmopolityzm (Werbner 2008), głoszony przez teoretyka zmiany politycznej Davida Helda w jego Democracy and the Global Order (1995), zainspirowanej Kantowskim Perpetual Peace, miał za zadanie podważyć utopijność kosmopolitycznego obywatelstwa. Kant ustanowił w nim prawo kosmopolityczne jako zbiór uniwersalnych zasad, które miały chronić ludzkość przed kolejnymi konfliktami. Zastosowanie kosmopolitycznego prawa człowieka do korzystania z powierzchni Ziemi miało za zadanie ostatecznie zakończyć rywalizację o terytoria. Kosmopolityczną strukturą społeczną nazywano wspólnotę wyznającą jednolite zasady. Współcześnie, z uwagi na inny zasięg przestrzenny, znaczenie kosmopolityzmu ponownie uległo znacznemu rozszerzeniu.

W moich badaniach narracje dotyczące mobilności często przejawiały zbieżność z koncepcjami analizującymi kosmopolityzm. Jest to pojęcie, które w potocznym rozumieniu oznacza szeroko pojętą otwartość. Niewiele to wnosi do rozumienia i możliwych interpretacji terminu. Słownik języka polskiego kosmo-

${ }^{6}$ Cosmopolitanism, w: Stanford Encyclopedia of Philosophy, http://plato.stanford.edu/entries/ cosmopolitanism/ (dostęp: 18.04.2019). 
polityzm definiuje jako: „pogląd negujący wszelkie podziały kulturowo-polityczne i terytorialne, więzi narodowe i tradycję, za prawdziwą ojczyznę człowieka uznający cały świat"”. Warto zatem przyjrzeć się badaniom nad kosmopolityzmem, które ukazują zniuansowanie oraz różnorodność interpretacji tego pojęcia.

Steven Vertovec i Robin Cohen (2002) dokonują podsumowania rozwijającej się literatury traktującej o kosmopolityzmie i proponują zamknięcie jej w sześciu ujęciach. Opierając się na perspektywie Vertoveca (2006), uważają, że pojęcie kosmopolityzmu może być rozumiane i używane jako: „(a) społeczno-kulturowa kondycja; (b) pewien rodzaj filozofii lub światopoglądu; (c) polityczne projekty nad budowaniem transnarodowych instytucji; (d) polityczny projekt służący rozpoznawaniu wielokrotnych tożsamości; (e) orientacja dotycząca postawy lub dyspozycji i/lub (f) sposób/tryb praktykowania lub kompetencji” (Vertovec, Cohen 2002: 7). Tak sformułowane sposoby interpretacji nadają pojęciu kosmopolityzmu pewną strukturę, która potencjalnie może zapobiegać nadużywaniu terminu $\mathrm{w}$ formach niesprecyzowanych. W kontekście moich badań rozumiem kosmopolityzm jako sposób/tryb operowania mobilnością, która w tym wypadku jest zarówno praktyką, jak i kulturową kompetencją. Jest to otwartość na interakcje $\mathrm{z}$ inną kulturą oraz umiejętność obcowania i dostosowania się do nowych kontekstów kulturowych, które pojawiają się wraz ze stworzeniem transnarodowego związku pomiędzy dwojgiem ludzi z różnych krajów. Kompetencja ta wynika z kapitału społecznego - edukacji, znajomości języków, ale także z gotowości do bycia mobilnym - motility. Holistyczny termin motility, łączący mobilność społeczną i przestrzenną, biorący pod uwagę nie tylko ruch geograficzny, ale także interakcję między jednostkami i kontekstami, wymianę dóbr oraz zarówno indywidualną, jak i międzypokoleniową zmianę społeczną, pozwala spojrzeć na kosmopolityzm jako na pewną strategię życia we współczesnym świecie. Oznacza to, że bycie kosmopolitą może, ale nie musi się wiązać wyłącznie z przestrzenną mobilnością, nie implikuje także wykorzenienia czy pełnej nieuwarunkowanej otwartości na każdą kulturę bądź braku uprzedzeń.

Bradley, 33-letni programista z Delaware, obecnie mieszkający z Agnieszką w Londynie, mówi tak: „Taa, to właśnie to, co miałem na myśli, że z kulturowego punktu widzenia oboje jesteśmy, ona szczególnie... ale oboje... Ja dużo podróżuję, właściwie jestem dosyć «światowy», "globalny»".

Zapytany o plan na przyszłość, Tom z Australii odpowiedział:

Znajdujecie swoją drogę i ta osoba po prostu cię wspiera. Dogadujecie się, ludzie rozumieją podobne rzeczy. Ona, tak jak ja, lubi miasta, oboje lubimy miasta nie za drogie... nie horrendalnie drogie. Londyn jest chory pod tym względem... Warszawa ma ten lokalny aspekt, jak inne miasta. Ona dobrze się czuje w Mediolanie, ja też, to wszystko się układa. Wiesz... nic nie jest ustalone, w sytuacji gdy ktoś nie chce gdzieś jechać. To jest podobny powód dla ciebie, bo to są te same etapy życia. Szczególnie takie aspekty jak kończenie nauki [...] Wiesz, jeśli powiem: „Jedź-

7 https://sjp.pl/kosmopolityzm (dostęp: 25.04.2019). 
my do Sydney albo do Australii”, to nic... jeśli mamy czas, bo ja bym chciał próbować, otworzyć się też dla niej, i myślę że ona byłaby „na tak” [...].

Sfery deklaratywne nie zawsze pozostają w zgodzie ze sferą praktyk rozmówców, jak również nie zawsze perspektywy te są jednakowe dla obydwu partnerów. Niektórzy z nich są przywiązani do miejsca pochodzenia i preferowaliby życie we własnym kraju. Jednak znacząca większość jest w stanie pójść na kompromis i osiągnąć konsensus dla dobra związku.

Ulf Hannerz uważa kosmopolityzm za zakorzeniony w praktyce - kulturowej kompetencji, praktykowanej, wyćwiczonej umiejętności, która poprzez system znaczeń (system of meanings) i formy znaczeniowe (meaningful forms) umożliwia mniej lub bardziej łatwy ruch (Hannerz 1990: 23). Twierdzi on, że obecnie istnieje jedna kultura, w której wszystkie struktury znaczeń i ekspresji są powiązane i stają się współzależne. Choć nie oznacza to całkowitej homogenizacji struktur, świat stał się jedną, wspólną siecią społecznych związków. Pomiędzy różnymi regionami następuje przepływ znaczeń, podobnie jak przepływ ludzi i dóbr. Kosmopolici to ci, którzy cenią różnorodność jako taką. Pnina Werbner zauważa, że termin został stworzony w kontrze do "globalizacji” rozumianej jako wolny od uwarunkowań, globalny (ale jednak głównie zachodni) ruch idei i praktyk. Kosmopolityzm powinien być zaś rozumiany jako przekraczający istniejące różnice kulturowe za pomocą dialogu, estetycznych korzyści i wspólnego szacunku dla życia ze świadomością różnic (Werbner 2008: 2). W tym duchu kosmopolici to ci, którzy nalegają na dostrzeżenie ludzkiej zdolności do wyobrażania sobie świata z perspektywy drugiej osoby, kulturowego Innego (Other), jak i do wyobrażania sobie możliwości istnienia świata kulturowego pluralizmu, pozbawionego granic. Takie podejście stworzyło warunki, by zarzucić pojęciu uprzywilejowanie, elitaryzm i europocentryzm (Robbins 1992: 169-183; Werbner 1999: 17-35; Werbner 2008: 16). Cohen i Vertovec piszą, że wielu badaczy krytykuje kosmopolityzm za jego hermetyczność, dostępność tylko dla tych, którzy posiadają środki potrzebne, by podróżować, uczyć się języków, poznawać inne kultury. Jednak co istotne, podczas gdy owa teza jest prawdziwa $z$ historycznego punktu widzenia, współcześnie kulturowa i językowa wszechobecność różnorodności sprawia, że kosmopolityzm staje się często aspektem życia codziennego (Vertovec, Cohen 2002: 5). Podobnie się dzieje w przypadku uczestników moich badań. Podejście Werbner pozostaje zgodne z perspektywą Cohena i Vertoveca. Autorka dodaje ponadto, że kosmopolityzm często jest rozumiany jako subiektywna zdolność, podczas gdy tak naprawdę sam w sobie jest produktem kreatywności i komunikacji, więc w kontekście różnorodności musi być rozumiany nie tylko na poziomie jednostki, ale przede wszystkim kolektywu, czegoś pokrewnego, relacyjnego, a zatem ulokowanego historycznie (Werbner 2008: 2). Podążając za tezą Jamesa Clifforda (1995: 107), który jako jeden z pierwszych zauważył, że porównywanie i tłumaczenie odmiennych, podróżujących kultur nie musi mieć charakteru ani klasowego, ani etnocentrycznego, antropolożka ta postuluje, by rozszerzyć termin kosmopolity- 
zmu i dostrzegać oraz badać także formy jego marginalnego, prowincjonalnego (parochial), regionalnego (vernacular) wymiaru (Werbner 2008; zob. też Bhabha 1996 i pierwsze użycie określenia vernacular cosmopolitanism).

Susanne Wessendorf (2010), opierając się na swoich badaniach w londyńskiej dzielnicy Hackney, proponuje pojęcie zwyczajnej, powszechnej różnorodności (commonplace diversity) i kosmopolityzmu sklepu na rogu (corner shop cosmopolitanism). Hackney jest dzielnicą zdywersyfikowaną kulturowo, w której w jednej, codziennej przestrzeni publicznej, jaką może być uliczny market, spotykają się różne nacje, kultury, religie, a międzynarodowe umiejętności są zinternalizowane i traktowane jako życiowy fakt. Jednym z przykładów kosmopolityzmu sklepu na rogu, jakie podaje Wessendorf, są działania tureckiego właściciela, który w swoim sklepie sprzedaje polskie piwo i kiszoną kapustę, a z uwagi na polską klientelę nauczył się przydatnych na co dzień zwrotów w języku polskim, co jest zatem pewną strategią poruszania się w kulturowo zdywersyfikowanym świecie. Taki rodzaj kosmopolityzmu jest charakteryzowany przez wszechstronne międzykulturowe umiejętności poruszania się we wspólnej przestrzeni społecznych relacji, zakorzeniony lokalnie w codziennych praktykach. Nie jest on ograniczony do podróżujących z łatwością elit, ale przybiera lokalne formy międzykulturowych negocjacji pomiędzy rezydentami z różnych społeczno-ekonomicznych etnicznych kontekstów i środowisk a tymi, którzy przybywają (Wessendorf 2010). Co istotne, życie w głęboko zdywersyfikowanym miejscu nie oznacza automatycznie lepszego rozumienia sposobu życia, postrzegania świata czy formowania znaczących, głębszych relacji przekraczających granice zarysowanych kulturowo bądź społecznie kategorii (Wessendorf 2010: 32). Może być jednak pragmatyczną codzienną strategią, potrzebą, jaką kreuje zróżnicowane kulturowo miejsce. Jeśli tak, nie wyklucza zatem społecznych napięć definiowanych przez społecznie rozgraniczone kategorie, takie jak etniczność, rasa, religia czy klasa, nie niweluje także stereotypów i czerpiących z nich uprzedzeń, nie implikuje świadomej tolerancji. Raczej współegzystuje z prowincjonalnością czy zaściankowością (parochialism). Antropolożka postuluje, by badać kosmopolityzm jako praktykę społeczną, jednocześnie nie zapominając, że otwartość tylko rozpoczyna spotkanie, nie jest zaś spotkaniem samym w sobie (Wessendorf 2010: 18). Potrzebne praktyki i umiejętności kulturowe, ułatwiające komunikację i interakcję z kulturowym „innym”, nazywane są wielokrotną kompetencją kulturową (multiple cultural competence) (Vertovec 2009: 7).

Współcześnie wiele badań analizuje obszary miejskie, w których kosmopolici są integralną częścią życia codziennego, zarówno ci pochodzący z mniejszości etnicznych, jak i z większości (Blokland 2003; Noble 2009). Powyższe rozumienie kosmopolityzmu wychodzi poza ramy potocznego, intuicyjnego rozumienia, przekracza dotychczasowe podziały, nie zakłada więc ani mylnej bezgraniczności, ani braku zakorzenienia czy wielości tożsamości. Zdaniem Werbner dotychczasowe wyparcie kosmopolityzmu ze społecznej antropologii związane jest $\mathrm{z}$ et- 
nograficzną tendencją do badania kultur jako zamkniętych całości, a to często uniemożliwia dostrzeżenie kosmopolitycznych cech, takich jak otwartość, wewnętrzna kontestacja, płynność czy mobilność.

Jak zauważa Vertovec (2009), pojęcie kosmopolitycznej kulturowej kompetencji (cosmopolitan cultural competence) wyraźnie rezonuje z innymi koncepcjami, w tym ze wspomnianą otwartością. Vertovec stwierdza, że kosmopolityczna kulturowa kompetencja związana jest $\mathrm{z}$ transnarodowym sposobem życia, co jest właśnie przypadkiem moich rozmówców.

W wielu parach, które badałam, kosmopolityczne podejście do planów na przyszłość zależy od partnera. Zwykle jedno z nich jest znacznie bardziej otwarte na możliwość potencjalnej zmiany, np. przeprowadzki do innego kraju, niż drugie. Mając na uwadze dobro związku, pary często deklarują kosmopolityczną otwartość, jednak gdy mowa o preferencjach, wielu z moich rozmówców mówi o przywiązaniu do miejsca, środowiska, rodziny lub po prostu kraju.

Julio jest z Argentyny, a Nina z Polski. W momencie przeprowadzania wywiadu oboje byli jeszcze $\mathrm{w}$ trakcie studiów. Julio zdobywał edukację, by zostać programistą, Nina studiowała prawo.

Dla mnie to jest niewyobrażalne. Bo u mnie, na przykład, nie będę mogła, nie będę w stanie pracować poza Polską. A poza tym ja sobie nie wyobrażam, że miałabym się przeprowadzić do Argentyny i robić coś zupełnie niezwiązanego ze swoimi studiami, no bo nie po to studiowałam pięć lat, żeby teraz... Więc bardzo się cieszę, że tak się zdarzyło, że może tu pracować w swoim zawodzie, że jest praca dla niego tutaj. Jemu się tutaj bardzo podoba, więc, no tak, więc w planach jest to, że on tu przyjedzie.

Z uwagi na wykonywany w przyszłości zawód Julio ma w ocenie Niny większe predyspozycje, by przeprowadzić się do Polski. Sama Nina zaznacza, że jest do Polski bardzo przywiązana, tu ma rodzinę i przyjaciół.

Większość moich rozmówców zamierza mieszkać w kraju rodzimym jednego z partnerów. Kosmopolityzm w przypadku uczestników moich badań jest zatem daleki od deklarowania nieuwarunkowanej otwartości na każdą destynację czy definiowania siebie jako obywatela świata. Komponent otwartości i elastyczności jest tu raczej wynikiem życia we współczesnym mobilnym świecie, dodatkowo zintensyfikowany przez transnarodowy związek na odległość. Motility stwarza warunki dla kosmopolitycznych praktyk, naturalizuje je i pomaga postrzegać jako coś możliwego i normatywnego. Mobilność przestrzenna jest $\mathrm{z}$ jednej strony kompetencją, z drugiej - społecznie wymaganą praktyką. Osoba, która nie byłaby zainteresowana żadną formą przestrzennej mobilności, która wymaga wyjazdu z własnego kraju, byłaby postrzegana jako zamknięta, uprzedzona bądź zwyczajnie niewystarczająco nowoczesna. W dzisiejszym świecie mobilność jest społecznym wymogiem, w przypadku ludzi żyjących w związkach na odległość staje się on jeszcze silniejszy. Zarówno ja, jak i moi rozmówcy traktujemy mobilność jako społeczną normę. To nasza wiedza ucieleśniona, część habitusu, coś, co jest już zrutynizowane, co zarówno ciało, jak i umysł zna i wie, jak wykonać. Pewnego 
rodzaju efekt opadu wartości i praktyk. Są one nie tylko reprodukowane, ale także produkowane na nowo.

\section{Związek jako transnarodowa sieć}

W momencie, w którym rozpoczyna się związek na odległość, wchodzi się w relacje i praktyki transnarodowe. Jeśli zdefiniujemy transnarodowość jako sieć łączącą ludzi i odległe od siebie miejsca (Glick Schiller 2012; Vertovec 2012), związek na odległość jest dla moich rozmówców taką właśnie siecią. W niektórych przypadkach ich relacja łączy dwa miejsca, dwa kraje, w innych cztery lub więcej. Bradley pochodzi z Delaware, gdzie mieszka jego rodzina, wyprowadził się do Nowego Jorku w poszukiwaniu lepszych perspektyw edukacji i pracy, obecnie mieszka z Agnieszką w Londynie. Agnieszka jest Polką, urodzoną w Warszawie, ale dotychczas całe swoje życie spędziła w Berlinie, gdzie nadal mieszka jej rodzina. Ich związek jest zatem swoistą siecią między Warszawą - gdzie podróżują, by odwiedzić część rodziny Agnieszki, Berlinem - gdzie przyjeżdżają, by spędzić czas z jej rodzicami i siostrą, Londynem - gdzie sami żyją, Nowym Jorkiem gdzie się poznali i przez jakiś czas mieszkali, więc przyjeżdżają tu, by odwiedzić przyjaciół, i Delaware, gdzie Bradley ma swoich bliskich.

Peggy Levitt i Nina Glick Schiller (2004) nazywają dotychczasową praktykę stosowaną $\mathrm{w}$ badaniach nad transnarodowością metodologicznym nacjonalizmem (metodological nationalism). Jest to istniejąca tendencja badaczy społecznych do akceptowania, a co się z tym wiąże - analizowania narodu jako państwa. Tendencja ta łączy się z procesem naturalizacji, traktowania jako dane, ustalone i oczywiste (taken for granted) granic państwa, które określają i definiują jednostkę analizy (Levitt, Glick Schiller 2004: 1007). By wyjść z tego impasu, badaczki proponują rozgraniczenie na kategorie: transnarodowych sposobów bycia (transnational ways of being) i transnarodowych przynależności (transnational ways of belonging). Sposoby bycia są tu powiązane najczęściej z istniejącymi praktykami społecznymi i relacjami migrantów, podczas gdy sposoby przynależności zakładają świadome utożsamienie się z daną grupą $\mathrm{w}$ ramach transnarodowych pól społecznych (Glick Schiller 2012: 26). Takie podejścia pozwalają patrzeć na jednostkę jako jednocześnie zaangażowaną $\mathrm{w}$ więcej niż jeden obszar państwa narodowego/narodu-państwa (nation-state), który wbrew dotychczasowym tendencjom nie definiuje i nie wyznacza granic społecznych relacji (Levitt, Glick Schiller 2004). Dlatego też „transnarodowe pola społeczne powinny być analizowane w odniesieniu do trajektorii życiowej jednostki i w powiązaniu ze zmieniającymi się warunkami narodowymi i globalnymi” (Glick Schiller 2012: 26). Odejście od skupienia się na tożsamościach narodowych na rzecz transnarodowych sposobów bycia i transnarodowych przynależności uważam za przydatne w moich badaniach. Jednym z pytań, jakie zadawałam, było pytanie o sytuacje, w których 
zachowanie partnera wydało się drugiej osobie niezrozumiałe. Pytałam też, czy to, że partner jest $\mathrm{z}$ danego kraju, jest w jakikolwiek sposób istotne dla relacji. W większości przypadków odpowiedzi na oba te pytania były negatywne („sytuacje takie się nie zdarzały, nie jest to dla mnie istotne") lub też kierowane wyraźnie w stronę osobowości, nie zaś jednej kultury czy narodowości. Większość uczestników moich badań mówiła nawet, iż narodowość ich partnerów jest zupełnie dla nich nieistotna.

Tak jak kosmopolityzm, transnarodowość nie musi oznaczać wykorzenienia. Nie musi także oznaczać łatwo definiowalnej, ograniczonej narodowo bądź etnicznie tożsamości. Moi rozmówcy są często zaangażowani na różne transnarodowe sposoby bycia. Jednym z pytań, jakie zadawałam, było pytanie o to, które miejsce jest bliższe ich sercu, które określają jako dom. Tom odpowiedział tak:

Bardzo trudno to tak ocenić. Choćby dlatego, że większość mojego życia spędziłem dotychczas w Anglii. I... mam tam dom, przyjaciół. Znam Anglię bardzo dobrze. Hmm... Londyn. Ale nie czuję do niego żadnego emocjonalnego przywiązania. Więc... Jestem wykorzeniony, jeśli chodzi o posiadanie konkretnego domu [...] dla mnie to jest... strasznie elastyczne, ponieważ mój konkretny emocjonalny dom jest pośrodku wsi we Francji, stąd pochodzą moi kuzyni i moja rodzina.

Wspomniana już Agnieszka, mówiąca w pięciu językach, urodzona w Warszawie, posiadająca rodzinę w Warszawie i Berlinie, mieszkała dotychczas w Niemczech, Stanach Zjednoczonych, a obecnie razem z Bradleyem mieszka w Anglii. Na pytanie o miejsce, które określiłaby jako dom, odpowiada tak:

A.: To znaczy... ciężkie strasznie, to taki temat numer jeden, tożsamość narodowa, blablabla, bo my z siostrą nigdy nie mieszkałyśmy w Polsce, możemy mówić, że jesteśmy Polkami, ale urodzone w Berlinie i mieszkające w Berlinie od dwudziestu paru, trzydziestu prawie lat, więc to ciężko powiedzieć.

A.S.: Obie się urodziłyście w Berlinie?

A.: Tak, dokładnie, ale dom nasz jest bardzo polski, mam nadzieję w dobrym tego słowa znaczeniu; chyba domem, domem jest na razie moje mieszkanie w Londynie, to jest naprawdę... To jest takie miejsce, że jak zamykam drzwi, to jest okej. Pamiętam, że... No wiesz, to jest też takie moje pierwsze własne mieszkanie, bez lokatorów, bez wynajmowania pokoi, pierdół. Więc to jest pierwsze takie mieszkanie, w którym mieszkam ja. [...] Kocham moje mieszkanko, ale tam, gdzie mama, to zawsze jest dom. Mama jest dla mnie taką osobą najlepszą na świecie, bohaterką, więc gdzie mama, tam dom, więc Berlin... To mieszkanie w Berlinie jest drugim domem, pierwszym... Nie wiem.

Na przykładzie podanych cytatów widać, jak trudno jest osobom zakorzenionym $\mathrm{w}$ różnych miejscach i zaangażowanym $\mathrm{w}$ różne przestrzenie określić jeden kraj, jeden dom, a co za tym idzie - jedną tożsamość. Wypowiedź Agnieszki dobrze ilustruje większą przydatność terminu przynależności transnarodowych, a znacznie mniejszą terminów kładących nacisk na jedną (państwową) narodowość.

Vertovec stawia tezę głoszącą, iż transnarodowość jest przejawem globalizacji. W tym duchu opisuje poszerzenie zjawiska transnarodowości z perspektywy 
zmian, jakie przyniósł rozwój telekomunikacji (Vertovec 2012). Zmiany te nazywa transformacjami społeczno-kulturowymi (Vertovec 2012: 59). Zdaniem Manuela Castellsa nowe technologie stanowią rdzeń dzisiejszych sieci transnarodowych (Castells 2007). Nie tworzą one nowych wzorców społecznych, ale wzmacniają już istniejące. Transformacje kulturowo-społeczne, o których pisze Vertovec, są na tyle znaczące, że obecnie zdanie Castellsa, w kontekście moich badań, przestaje być prawdziwe. Albowiem trzy pary z dziesięciu poznały się przez aplikację o nazwie Tinder, która powstała w 2012 roku, tak więc relacja nie tylko jest utrzymywana za pomocą technologii, ale także została z jej pomocą zainicjowana. Został stworzony pewien nowy, obecnie coraz bardziej powszechny wzorzec społeczny, który akceptuje relację zawiązaną przez technologie. Robin Cohen pisze, że współcześnie transnarodowe więzi nie muszą być redukowane do terytorialnej wyłączności, ponieważ w „erze cyberprzestrzeni diaspora może być utrzymywana i stwarzana na nowo, za pomocą kulturowych artefaktów oraz wspólnych wyobrażeń" (Cohen 1996: 516).

Przeprowadzone przeze mnie badania pokazują, iż związki na odległość, zawiązywane pomiędzy osobami z dwóch różnych krajów, splatają dwie, wcześniej odrębnie wytworzone przez każdego z partnerów, sieci ludzi (przyjaciół, znajomych, członków rodzin) i miejsc w jedną ogromną sieć. Transnarodowa sieć może obejmować dwa, trzy lub więcej krajów. Zawiązuje się ona ponad granicami przestrzeni państw narodowych i jest podtrzymywana za pomocą technologii. W miarę upływu czasu może się dalej rozrastać.

\section{Wnioski}

Znaturalizowana mobilność, która staje się częścią procesu socjalizacji i codzienności, powoduje, że takie pojęcia jak kosmopolityzm czy transnarodowość poszerzają swoje znaczenia. Sprawia, że terminy te coraz częściej znajdują się w spektrum zainteresowań antropologii. Wielość definicji nie wpływa negatywnie na przydatność pojęcia, dopóki badacze społeczni dookreślają znaczenia i dostosowują je do obranego przez siebie tematu badań. Dobrą strategią jest podążanie za lokalnymi kategoriami stosowanymi przez naszych rozmówców, potraktowanie common sense jako punktu wyjścia przy tworzeniu definicji.

W kontekście moich badań transnarodowych związków na odległość takie pojęcia jak motility (rozumiane zarówno jako kompetencja kulturowa, jak i gotowość do bycia mobilnym), kosmopolityzm (definiowany jako sposób/tryb operowania mobilnością, która w tym wypadku jest praktykowaną strategią wymagającą społecznych kompetencji) i transnarodowość (w znaczeniu sieci łączącej ludzi i miejsca, jaka tworzy się za pomocą związku) nierozłącznie splatają się ze sobą. Motility dokumentuje trudno zauważalne związki pomiędzy przestrzenną mobilnością a tym, co na nią wpływa i warunkuje ją społecznie. Pomaga dostrzec war- 
tości, znaczenia, zmiany społeczne, czyli to, co stoi za widzialnym przestrzennym ruchem, za pojęciem mobilności. Pozwala także postrzegać społeczną zmianę jako proces i uchwycić codzienne praktyki, które się na nią składają. W badanym przeze mnie kontekście etnograficznym motility, kosmopolityzm i transnarodowość są ze sobą powiązane. Analizowane praktyki rozmówców często wskazują na współwystępowanie omawianych zjawisk w różnych konfiguracjach.

W moich badaniach motility ujawnia swój holistyczny charakter, jest pośrednią przyczyną zawiązania związku na odległość z osobą z innego kraju, ale i konsekwencją tej relacji. Osoby żyjące w takim związku muszą pozostać elastyczne w sferze mobilności, by relację utrzymać oraz by móc planować wspólną przyszłość. Ponadto motility stwarza warunki dla powstania kosmopolitycznych strategii. Kosmopolityczne wybory, jakich dokonują wspomniane osoby, świadczą więc z jednej strony o opanowaniu społecznie wymaganej praktyki kulturowej, z drugiej są konsekwencją czasów, w jakich żyją, oraz sposobu życia wywołanego przez transnarodowy związek na odległość.

Przeprowadzone przeze mnie badania pokazują także, że wbrew temu, co uważają badacze nowoczesności, tacy jak między innymi Zygmunt Bauman (2000; 2003) czy Anthony Giddens (1992), współczesne związki nie muszą być pozbawione odpowiedzialności, niegodne zaufania, chaotyczne czy fragmentaryczne. Wbrew złudzeniu płynnej nowoczesności struktura w dalszym ciągu istnieje, a takie pojęcia jak mobilność, transnarodowość czy kosmopolityzm mogą być jej częścią. Związek na odległość sprawdza umiejętność panowania nad strukturą, którą sam narzuca, testując kompetencje kulturowe, wymagając od partnerów bycia i pozostania w ruchu. Potencjalnie wymaga od partnerów więcej niż związek „normatywny”. Ponagla etapy relacji, zobowiązuje do dojrzałości i wspólnego zaufania. Egzekwuje umiejętność planowania i zarządzania zarówno emocjami, jak i czasem. W makroskali jest wynikiem współczesnych, płynnych, mobilnych czasów, ale także układem, który daje tymczasową możliwość spełnienia norm społecznych, pogodzenia samorozwoju z życiem osobistym. W skali mikro jest próbą siły, wytrwałości i zaufania, sprawdzianem zarówno dla pary, jak i dla jednostki.

\section{Bibliografia}

Bauman Z.

2000 Liquid Modernity, Cambridge.

2003 Liquid Love. On the Frailty of Human Bounds, Cambridge.

Bhabha $\mathrm{H}$.

1996 Unsatisfied: Notes on Vernacular Cosmopolitanism, w: L. Garcia-Morena, P.C. Pfeifer (eds.), Text and Nation: Cross-Disciplinary Essays on Cultural and National Identities, London, s. 191-207.

Blokland T.

2003 Urban Bonds, Cambridge. 
Bourdieu P.

1984 Distinction. A Social Critique of the Judgement of Taste, Cambridge.

Castells M.

2007 Społeczeństwo sieci, przeł. M. Marody, K. Pawluś, J. Stawiński, S. Szymański, Warszawa.

Clifford J.

1995 O autorytecie etnograficznym, przeł. J. Iracka, S. Sikora, „Konteksty. Polska Sztuka Ludowa”, nr 49 (3-4), s. 230-231.

Cohen R.

1996 Diasporas and the Nation-State: From Victims to Challengers, „International Affairs", nr 72 (3), s. 507-520.

Fischer E.F.

2014 The Good Life: Aspiration, Dignity, and the Anthropology of Wellbeing, Stanford.

Giddens A.

1992 The Transformation of Intimacy, Cambridge.

Glick Schiller N.

2012 The Transnational Migration Paradigm. Global Perspectives on Migration Research, w: D. Halm, Z.S. Abingdon (eds.), Migration and Organized Civil Society. Rethinking National Policy, New York, s. 25-43.

Hannerz U.

1990 Cosmopolitans and Locals in World Culture, „Theory Culture Society”, nr 7, s. 237-251.

Harvey D.

1990 The Condition of Postmodernity, Oxford.

Held D.

1995 Democracy and the Global Order: From the Modern State to Cosmopolitan Governance, Stanford.

Kaufmann V., Bergman M.M., Joye D.

2004 Motility: Mobility as Capital, „International Journal of Urban and Regional Research", nr 28 (4), s. 745-756.

Kesselring S.

2006 Pioneering Mobilities - New Patterns of Movement and Motility in a Mobile World, „Environment and Planning” A, nr 38, s. 269-279.

Levitt P., Glick Schiller N.

2004 Conceptualizing Simultaneity: A Transnational Social Field Perspective on Society, „International Migration Review”, nr 38 (3), s. 1002-1039.

Noble G.

2009 Everyday Cosmopolitanism and the Labour of Intercultural Community, w: A. Wise, S. Velayutham (eds.), Everyday Multiculturalism, Basingstoke, s. 47-67.

Nowicka M., Rovisco M.

2009 Introduction: Making Sense of Cosmopolitanism, w: M. Nowicka, M. Rovisco (eds.), Cosmopolitanism in Practice, London-New York, s. 1-16.

Robbins B.

1992 Comparative Cosmopolitanism. Social Text, JSTOR, 31 (32), s. 169-186, www. jstor.org/stable/466224 (dostęp: 22.11.2019).

Vertovec S.

2006 Fostering Cosmopolitanisms: A Conceptual Survey and a Media Experiment in Berlin, w: A. Dallmann, G. Lenz, F. Ulfers (eds.), Toward a New Metropolitanism: 
Reconstituting Public Culture, Urban Citizenship, and the Multicultural Imaginery in New York and Berlin, Heidelberg, s. 277-298.

2009 Transnationalism, London.

2012 Transnarodowość, przeł. I. Kołbon, Kraków.

Vertovec S., Cohen R.

2002 Introduction: Conceiving Cosmopolitanis, w: S. Vertovec, R. Cohen (eds.), Theory, Context and Practice, Oxford, s. 1-23.

Werbner P.

1999 Global Pathways: Working Class Cosmopolitans and the Creation of Transnational Ethnic Worlds, „Social Anthropology”, nr 7 (1), s. 17-35.

Werbner P.

2008 Introduction: Towards a New Cosmopolitan Anthropology, w: P. Werbner (ed.), Anthropology and the New Cosmopolitanism: Rooted, Feminist and Vernacular Perspectives, New York, s. 1-30.

Wessendorf S.

2010 Commonplace Diversity: Social Interactions in a Super-Diverse Context, MMG Working Papers WP 10-11, Max Planck Institute for the Study of Religious and Ethnic Diversity, Göttingen, s. 1-36. 